\title{
IDENTIFYING POTENTIAL RISK FOR SAFETY IN THE TRAINING OF SPECIALTY "HEAT AND GAS SUPPLY"
}

\author{
Ivan Lazarov, Nely Georgieva, Miroslav Bilarev, \\ Ivo Mihov, Nikolay Todorov \\ Trakia University, Faculty of Technics and Technologies \\ 8600 Yambol, Bulgaria, +359878115586, e-mail: isl51@abv.bg
}

\begin{abstract}
To increase energy reliability in the European Union (EU) is necessary the formation of a new energy policy and energy infrastructure in Europe. It should be oriented to reduce harmful emissions, climate change mitigation and ensuring of accessible and secure energetics for all consumers. The successful realization of this new EU energy policy requires the provision of significant financial resources and a suitable highly qualified human potential. With its introduction is imperative introduction of new, integrated educational policy. This educational policy must be consistent with the challenges and the needs of the new time. First, it must ensure the safety and health of workers by adequate risk management in the working / learning environment. In this work procedural aspects in identifying and categorizing of the risk are discussed. The aim is to ensure the safety and health in working / learning environment in accordance with applicable law.
\end{abstract}

Keywords: identifying potential risk, safety.

\section{INTRODUCTION}

To increase energy reliability in the European Union (EU) is necessary the formation of a new energy policy and energy infrastructure in Europe. It should be oriented to reduce harmful emissions, climate change mitigation and ensuring of accessible and secure energetics for all consumers.

The successful realization of this new EU energy policy requires the provision of significant financial resources and a suitable highly qualified human potential. With its introduction is imperative introduction of new, integrated educational policy. This educational policy must be consistent with the challenges and the needs of the new time. First, it must ensure the safety and health of workers by adequate risk management in the working / learning environment.

In this work procedural aspects in identifying and categorizing of the risk are discussed. The aim is to ensure the safety and health in educational - technological environment (ETE).

About this policy, according to Art. 165 and Art. 166 of the Treaty on the Functioning of the European Union (TEC) - Title XII, Education, vocational training ...) [4], "The contribution of the EU to development of quality education and conducting vocational training policy involves a fully respect the responsibilities Member States for the content of teaching, organization of education systems and vocational training ....

In this aspect, some of the actions of the EU are directed towards:

- developing the European dimension in education, particularly through the teaching and dissemination of the languages of the Member States;

- encouraging cooperation between educational institutions;

- developing exchanges of information and experience on issues that are common to the education systems of the Member States;

IRTIIE Vol. 5, No. 1, 2017 ISSN 1314-8788 (print), ISSN 1314-8796 (online), doi: 10.15547/artte.2017.01.008 


\section{IRITIE}

- facilitate adaptation to industrial changes, in particular through vocational training and retraining;

- improving initial and continuing vocational training in order to facilitate vocational integration and reintegration into the labor market;

- facilitating access to vocational training and encouraging mobility of instructors and trainers and particularly of the young people;

- stimulating cooperation on training between educational or training institutions and companies".

\section{DESCRIPTION OF THE PROBLEM}

In the management of safety in conducting the practical training imposes implementation of the so-called systematic approach. According to the general theory of the systems, the binary model "TRAINER - LEARNER" can be presented as an organized aggregate of interacting elements forming a single entity, i.e. as a system.

In the context of risk management, the process of practical training (PT) consists of multiple interconnected elements (resources, contractors, documentation, etc.) aimed at safely achieve certain educational and training goals.

In practical training the reliability $R_{S}$ of ternary system "PROCESS - ENVIRONMENT person" (PEP) is a product of multiple risk factors $\mathrm{R}_{i}$, and is determined by the dependence:

$$
\mathrm{R}_{\mathrm{S}}=\prod_{i=1}^{n} R_{i}=\mathrm{R}_{\mathrm{T}} \cdot \mathrm{R}_{\mathrm{C}} \cdot \mathrm{R}_{\mathrm{A}}
$$

Where:

$\mathrm{R}_{\mathrm{T}}$ is the risk arising as a result of the influence of technogenic factors on the safety and health at the practical training (SHPT);

$\mathrm{R}_{\mathrm{C}}$ - the risk arising as a result the impact of the educational - technological environment (ETE) on the SHPT;

$\mathrm{R}_{\mathrm{A}}$ - the risk arising as a result the influence of anthropogenic factors on the SHPT;

$\mathrm{n}$ - the number of elements in the system.

Assessing the safety risk is composed of two phases: risk analysis for safety and risk assessment.

The analysis of technogenic (technical, technological) safety risk involves identifying hazardous events and defining elements of risk $R_{i}$ for SHPT by the equality:

$$
R_{T i}=P_{T i} . F_{T i} \cdot C_{T i},
$$

Where:

$i$ is the serial number of current technological operation;

$P_{T i}$ - the probability of occurrence of the danger of the current technological operation (an index of the probability);

$F_{T i}$ - the frequency of the danger in the execution of the current technological operation (the frequency index);

$C_{T i}$ - the influence of the result from implementation of the danger in the current technological operation (an index of the influence).

The risk $R_{A}$ arising into ETE under the influence of $n$ number concurrent anthropogenic risk factors are determined by the formula: 


\section{IRITIE} Ipplied Reserertches in Technics, Technologies and Bduration Journal of the Faculty of Technics and Technologies, Trakia University https:///ites.google.com/a/trakia-uni.bg/artte/

$$
R_{A}=\prod_{i=1}^{n} P_{i} \cdot F_{i} \cdot C_{i}
$$

Where:

$i$ is the serial number of current anthropogenic risk factor influencing the SHPT;

$P_{i}$ - probability of danger in ETE under the action of the i-th anthropogenic risk factor (an index of the probability);

$F_{i}$ - frequency of dangers in ETE under the action of the i-th anthropogenic risk factor (the frequency index);

$C_{i}$ - the influence of the result from implementation of the danger in ETE under the action of the i-th anthropogenic risk factor (an index of the influence).

From the formula (3) is evident that for the determination of $R_{A}$ is required to be previously calculated the probability $P_{i}$.

The purpose of this study is by presenting the learning process as a complex of logically structured methodical units, the procedures for identifying and categorizing the dangers ETE in accordance with the applicable rules of law are analyzed, as a preliminary stage of assessing the risk for SHPT in specialty "Heat and gas."

\section{PREREQUISITES TO IDENTIFY POTENTIAL RISK}

\section{Concerning the legislative and regulatory framework}

To ensure SHPT and risk assessment in ETE the Ministry of Education need to establish ndustry standards (unified methodology) harmonized with Decree № 5 based on the concept of regulation. It must take into account the specificity of the educational activity (technogenic factors, educational qualification status (EQS) and psycho-physiological status (PPS) of the learners, technology training, etc.) And indicate clearly the methods, stages, activities and criteria for risk regulation in ETE.

\section{Concerning the methods of risk assessment in the learning environment}

The study of risks for SHPT is possible through the application of expert methods based on the questionnaire surveys and taking into account the specific conditions in ETE, and the complex influence of factors from the system "Process - Environment - Person" on the trainees.

\section{DESCRIPTION OF THE SUBJECT OF THE IMPACT OF POTENTIAL RISK}

If the element 'Learner' by the subsystem "Person" is presented as an object of risk influences:

- The reliability of the learner consists of its ability to perform prescribed functions without mistakes and failures in a given system under certain conditions and for a certain period of time.

- In the context of the theory of the reliability, failure is total or partial loss of the person's ability to perform certain functions.

- In a narrower sense, a refusal of the learner is discontinuation of work due to stress effects, violation of operating regime, errors in perception and explores the adoption of decisions, implementation of management actions.

IRTIIE Vol. 5, No. 1, 2017 ISSN 1314-8788 (print), ISSN 1314-8796 (online), doi: 10.15547/artte.2017.01.008 


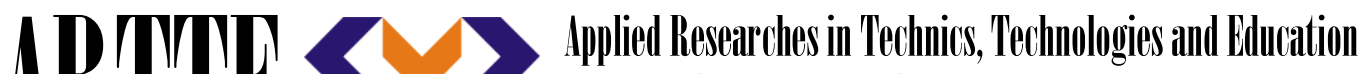 Journal of the Faculty of Technics and Technologies, Trakia University https://sites.google.com/a/trakia-uni.bg/artte/}

- The probability of reliable operation (operation reliability) learner $P_{0}(t)$ for the time $t$ is determined by the expressions:

$$
\begin{gathered}
P_{O}(t)=K_{K} \cdot P_{P P}(t), \\
P_{P P}(t)=P_{\Phi}(t) \cdot P_{\Pi}(t),
\end{gathered}
$$

Where:

$K_{\mathrm{K}}$ is the qualification coefficient accounting qualification reliability (standby) of the learner during PT at any moment $t$ - Reflects the probability of absence of errors in the work of learner because of insufficient level of acquired professional knowledge, practical skills and formed practical skills and experience (EQS) at some point in the training cycle $T_{0}$;

$\mathrm{P}_{\mathrm{PP}}$ - psycho-physiological reliability of the learner;

$\mathrm{P}_{\phi}$ Physiological reliability - reflect the probability of absence of errors in the work of learner caused by the impact of physiological risk factors for time $t$;

$\mathrm{P}_{\Pi}$ - psychological reliability (infallibility) - reflects the probability of absence of errors in the work of learner caused by the impact of psychological risk factors for time t.

\section{Characteristics of the "process-environment-person"}

- The system PEP is composed of three interrelated and interdependent subsystems "Process", "Environment" and „Person", each of which is a source of multiple risk factors (RF) which have a complex impact on SHPT.

\section{PROCEDURE FOR ASSESSING THE RISK FOR SAFETY}

Risk assessment - stages:

1. Classification of work activities;

2. Identification of hazards in various work activities;

3. Determination of employees exposed to hazards;

4. Defining elements of the risk;

5. Risk Assessment;

6. Documentation.

\subsection{Procedure for classification of work activities}

- Establishing the list of work activities of the evaluated objects - sequence:

- Curriculum of specialty "Heat and gas supply";

- Specific courses of specialty "Heat and gas supply"- mandatory and optional;

- Thematic plan for the practical exercises for each discipline;

- Grouping of work activities in a rational way of assessing risk;

- Collecting the necessary information for work activities - typical hazards, regulations, measures for the protection and any other information needed to assess of the risk.

\subsection{Procedure for identification of hazards}

- Establishing of:

- presence of hazards and comparative analysis of hazards priorities;

- possible ways and means for impact of hazards;

- objects that can be damaged - people, property, labor or environment;

IRTIIE Vol. 5, No. 1, 2017 ISSN 1314-8788 (print), ISSN 1314-8796 (online), doi: 10.15547/artte.2017.01.008 


\section{ARTIL

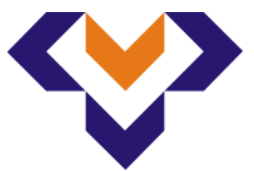 \\ Ipplied Ressearthes in Technics, Technologies and Bductation Journal of the Faculty of Technics and Technologies, Trakia University https://sites.google.com/a/trakia-uni.bg/artte/}

- Systematic study of all aspects of the activity:

- analyzing all activities that occur on the subject property;

- reporting unusual operation during activities;

- reporting of unplanned, but foreseeable events;

- giving into account the possibility of industrial accidents;

- analysis of provisions to ensure healthy and safe working conditions and implemented safeguards;

- Determining those aspects of the activities that can cause damage;

- Giving accounts not only the dangers but also the way of interaction of employees with dangers and how this alters risk.

Identified hazards are categorized into groups depending on their type and nature.

\subsection{Potential risk factors subsystem "ENVIRONMENT"}

- Microclimate (climate) risk factors - temperature, humidity, pressure, movement and ionization and air quality, dust;

- Sanitary and hygienic risk factors;

- Socio-psychological risk factors;

- Ergonomic risk factors;

- Aesthetic risk factors.

\subsection{Potential risk factors subsystem "PERSON"}

- Psycho-physiological risk factors - medical, mental and physiological condition;

- Qualifying risk factors - training and qualifications for operating machines and high-risk facilities;

- Physical risk factors - physical condition;

- Anthropometric risk factors - appropriate structure, adaptation and furniture design; work areas and positions.

\subsection{Potential risk factors subsystem "PROCESS"}

Physical risk factors, including risks associated with working equipment - equipment, machinery, appliances, tools, etc.) - occurs due to lack, inadequacy or failure of hazardous systems or systems for safety equipment;

- Technical risk factors (safeguard of working equipment), including:

- Mechanical risk factors - manual handling of weights dangers of overloading (static, dynamic), fatigue, stress, danger of damage to body parts;

- Electric risk factors;

- Fire hazard;

- Risk of explosion;

- Optical risk factors;

- Technological risk factors - arise because of the interaction between objects (person equipment - material) of the system in a working environment; associated with:

○ the technological process - method, manner, procedure, operation and others.;

- the technological materials - basic and auxiliary, raw materials, blanks, supplies, semi-finished and others.;

- used energy - electric, pneumatic, hydraulic, thermal and others;

- the technological product - product, detail, by-product, secondary energy.

- Acoustic risk factors;

IRTIIE Vol. 5, No. 1, 2017 ISSN 1314-8788 (print), ISSN 1314-8796 (online), doi: 10.15547/artte.2017.01.008 


\section{IR'TIE

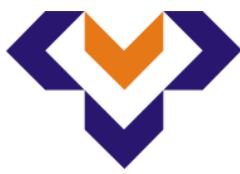

Ipplied Resseirl'hes in Technics, Technologies and Bductation Journal of the Faculty of Technics and Technologies, Trakia University https://sites.google.com/a/trakia-uni.bg/artte/

- lonizing risk factors;

- Ray risk factors;

- Vibration risk factors;

- Chemical risk factors, including:

- Chemical substances (toxicity);

- Cleanliness air;

- Biological risk factors, including:

- Microbiological risk factors;

- Risks due to plants;

- Risks due to animal.

\section{MAIN CONCLUSIONS}

The results of the studies give rise to the following conclusions:

- The analysis has identified the need to correct selection of methods and tools to identify potential risk factors for safety training in specialty "Heat and gas supply".

- It was found that by applying suitable modern preventive methods and tools it is possible to minimize the impact on the RF on the learners.

- It should be composed methodology for assigning risk levels of individual effect of each RF in SHPT.

\section{REFERENCES}

[1] BDS 16344-85. System ergonomics. Methods of analysis and assessment of the reliability of the system "person-machine". General (in Bulgarian).

[2] Safety and Health at Work. Handbook for independent audit in small and medium enterprises. S., EU Commission and the Ministry of Health, "Schedule Consult Ltd", 1998. (in Bulgarian).

[3] Bragin, V., F.Chabon Assessment of risk and consequences of failure of complex systems, structures and processes. Magazine "The market and the quality of Yaroslav", 1997, № 1, Yaroslavl. (in Russian).

[4] Treaty on European Union and Treaty on the Functioning of the European Union. Consolidated versions of the Treaty on European Union and the Treaty on the Functioning of the European Union OJ C 326, 26.10.2012, p.1. https://www.ecb.europa.eu/ecb/legal/pdf/c_32620121026en.pdf, available 04.01.2017.

[5] Dropo, G., D.Bley Methodology risk of technological consequences. S., Collection REPORTS. of Int. Learn. Session UMG "Management of natural and technogenic risks," IK "St. Ivan Rilski "2001. (in Bulgarian).

[6] Law on health and safety at work (publ. State Gazette №124 of 23.12.1997) (in Bulgarian).

[7] Law on fire protection (publ. State Gazette №89/1979) (in Bulgarian).

[8] Kozlov, V.I. The methodology of occupational safety in man - machine systems, Riga, "Zinatne", 1989. (in Russian).

[9] Labour Code, (publ. State Gazette №100/1992).

[10] Constitution of the Republic of Bulgaria.

[11] Manolov, M. (ed.) Manual for assessing the risk to health and safety of employees at work. Shumen, "Chimera" Ltd., 2001. (in Bulgarian).

[12] Ordinance comprehensive assessment of working conditions, MLSW and MH (publ. State Gazette №73/1991).

[13] Ordinance № 3 of 14.05 .1996 for briefing employees on safety, hygiene and fire safety. MLSW and MH (publ. State Gazette №44/21.05.1996).

IRTIIE Vol. 5, No. 1, 2017 ISSN 1314-8788 (print), ISSN 1314-8796 (online), doi: 10.15547/artte.2017.01.008 


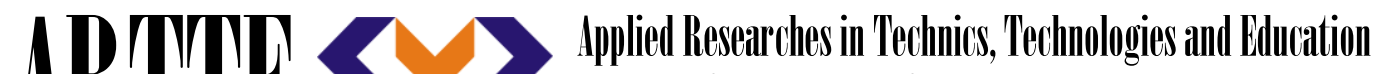 Journal of the Faculty of Technics and Technologies, Trakia University https://sites.google.com/a/trakia-uni.bg/artte/}

[14] Ordinance № 5 of 11.05 .1999 on the terms, manner and frequency of assessment of risk. MLSP and MH, (publ. State Gazette №47/ 21.05.1999).

[15] Ordinance № 7 of 23.09.1999 for minimum health and safety in workplaces and the use of working equipment, MLSP and MH, (publ. State Gazette №88/8.10.1999).

[16] Handbook for risk assessment. Ministry of Education and Science, 2002. (in Bulgarian).

[17] Regulations for industrial safety of students when conducting product training and production practices. Ministry of Education, 1961. (publ. State Gazette №12/10.11.1961).

[18] Regulations for labor safety in mechanical (cold) processing of metals (D-01-012). S., Ministry of Labour and Social Affairs, 1975 (amend. and suppl., IBT of MLSA, №.1161991).

[19] Regulations for labor safety in loading and unloading (D-05-001). MLSA, 1972.

[20] Manual for systems for managing health and safety in the workplace BS 8800: 1996. S., "Bulletin for the latest information in the field of quality" issue. 4 Association "Club 9000", 2001. (in Bulgarian).

[21] Manual for occupational risk assessment. S., MLSA, GLI, CTC, 1997. (in Bulgarian).

[22] Manual for occupational risk assessment in the workplace. S., MLSb, GLI, CTC, 1997. (in Bulgarian).

[23] Guidance for assessing workplace. (Ed. Prof. E.Ivanovich, MD) S., IB and NCHMEN "Schedule Consult Ltd", 1998. (in Bulgarian).

[24] Savova, B. (ed.) Risk assessment in the workplace. S., "Viola", 2000. (in Bulgarian).

[25] Tasev, G. Expert methods for risk assessment. S., Union of Quality Specialists in Bulgaria, 2003. (in Bulgarian).

[26] Tomov V. Industrial and environmental security. Varna, Publ. VSU "Chernorizets Hrabar", 2002. (in Bulgarian).

[27] Tomov V. Theory of risk. Ruse, RU "A.Kanchev"2003. (in Bulgarian). 